\title{
Compulsory Arbitration and the Right to Strike: The Experience of Alberta's University Faculty
}

\author{
Jeffery Taylor Athabasca University
}

\begin{abstract}
Résumé
En Alberta, le personnel universitaire respecte un régime de convention collective dans lequel un arbitrage obligatoire remplace la grève ou le lockout en cas de désaccord sur le renouvellement de contrats. Comment en est-on arrivé là? Et en quoi s'est traduit, dans la pratique, le régime d'arbitrage de différends? Le présent article explore ces questions en se penchant sur les origines des conventions collectives pour les associations d'universitaires en Alberta, en retraçant la pratique de l'arbitrage au cours des trente dernières années et en se penchant de plus près sur un ensemble de quatre arbitrages entre 2001 et 2003. En conclusion, l'article demande s'il ne serait pas temps pour les associations de personnel universitaire d'affirmer leur droit fondamental à faire grève, nonobstant la teneur de leur convention collective ou les statuts gouvernant leur négociation collective.
\end{abstract}

\begin{abstract}
University academic staff in Alberta operate under a collective bargaining regime in which compulsory arbitration replaces strike/lockout to resolve disputes over contract renewal. How did this come about? And what has the experience been under a regime of interest arbitration? This paper addresses these questions by investigating the origins of faculty association collective agreements in Alberta, tracing arbitral experience over the past thirty years, and looking more closely at a group of four arbitrations in 2001-2003. The paper concludes by asking whether it is time for academic staff associations to assert their fundamental right to strike, regardless of what is in their collective agreements or in the statute governing their collective bargaining.
\end{abstract}




\section{Introduction}

In March of 2004 the Alberta government proclaimed Bill 43, the Post-Secondary Learning Act, which combined a number of existing statutes governing post-secondary institutions in the province. When it was introduced in the legislature in the spring of 2003, Bill 43 contained an explicit ban on the right of academic staff associations to strike. In its response to Bill 43, the Confederation of Alberta Faculty Associations (CAFA) called this aspect of the bill a "gratuitous insult" to academic staff. Indeed, the four collective agreements between university governing boards and faculty associations in the province all contain compulsory arbitration as the dispute-resolution mechanism. Banning strikes and lockouts for this group of workers, therefore, appeared to be a case of overkill on the part of an admittedly very conservative provincial government. ${ }^{1}$

In fact, the comparatively well-behaved university professors were not the impetus for this new provision. The new act governs colleges and institutes as well as universities, including collective bargaining between academic staff and governing boards at all of the province's public post-secondary institutions, and it was a college academic staff association that was the target of the new attack on the right to strike. Of all the collective agreements covering college, institute and university faculty in Alberta when the new legislation was introduced, only the one at Mount Royal College contained language permitting strikes to resolve disputes. Binding arbitration was in place at all of the other institutions. But during negotiations for a new collective agreement in 2002, the Mount Royal College Faculty Association laid the groundwork for a possible strike by conducting a strike vote and undertaking some work-to-rule actions as part of its bargaining strategy. While a negotiated settlement was reached at Mount Royal before a strike was called, it is clear to most observers that the ban on strike/lockouts in the first draft of the PostSecondary Learning Act was a direct response to events at Mount Royal College.

A number of amendments were made to the bill between the first and final drafts. Initially, the explicit ban on strikes and lockouts was removed and replaced with language specifying that binding arbitration would be the final dispute-resolution mechanism for all bargaining between academic staff and governing boards in colleges and universities. At three universities, however, bargaining is divided between salaries and benefits bargaining, which is subject to binding arbitration, and "handbook" or "terms and conditions" (contract language) bargaining, which requires mutual agreement between the

\footnotetext{
"In Canadian labour law an "interest dispute" is a dispute over the negotiation of the terms of a collective agreement. This is distinguished from a "rights dispute," which is a dispute over the interpretation or application of a collective agreement. Although it is severely circumscribed, most unionized Canadian workers have a legal right to strike over interest disputes. All unionized Canadian workers, however, are legally barred from striking during the life of a collective agreement and must follow compulsory grievance arbitration procedures for the resolution of "rights disputes" over the interpretation and application of contract language. This, arguably, in an equally egregious and uniquely Canadian infringement of workers' rights. On the distinction between interest and rights disputes, see, for example, Weiler (1980: 91). On the denial of the right to strike during the term of a collective agreement, see, for example, Haiven (1995).
} 
parties for any change and for which there is no final dispute-resolution mechanism. CAFA protested that the proposed change would have the unintended effect of expanding the ambit of binding arbitration to include bargaining over contract language. Ministry bureaucrats agreed and altered the legislation to ensure that the status quo prevailed at the four existing universities, since it corresponded in any event to the intent of the legislation not to allow strikes or lockouts. But the explicit provision for binding arbitration applied to all colleges and any universities that might be established in the future. Whereas the old Universities Act allowed strike/lockouts, but specified that binding arbitration would be used to resolve disputes in the absence of an alternative dispute-resolution mechanism, the new Post-Secondary Learning Act clearly prohibits strikes and lockouts for college and university academic staff, despite the differing language for colleges, existing universities and potentially new universities. In the unlikely event that a faculty association at an existing university was able to persuade its board of governors to negotiate a strike/lockout provision, it is reasonable to predict that the legislation would be amended to make it illegal.

Academic staff in Alberta, then, operate under a collective bargaining regime governed by the Post-Secondary Learning Act and in which compulsory arbitration replaces strike/lockout to resolve disputes over contract renewal. How did this come about? Furthermore, what has their experience been under a regime of interest arbitration? This paper addresses these questions by investigating the origins of faculty association collective agreements in Alberta, tracing arbitral experience over the past thirty years, and looking more closely at a group of four arbitrations in 2001-2003. The paper concludes by asking whether it is time for academic staff associations to assert their fundamental right to strike, regardless of what is in their collective agreements or in the statute governing their collective bargaining.

\section{The Historical and Legal Context}

Alberta has the most employer-friendly and anti-worker labour laws in Canada. Very few public sector workers have the legal right to strike and many aspects of the employment relationship are beyond the scope of bargaining in the public sector. The Labour Relations Code, which covers the private sector and parts of the public sector, has an extensive list of exclusions and requires a vote on all certification applications. As a result of this legislative regime, union density is the lowest in the country (22.5\% in 2001) and strike activity is well below the Canadian average. Furthermore, Alberta has an established system of non-union representation (employer-controlled employee associations), especially in its dominant energy sector (Ponak, Reshef, and Taras, 2003).

Alberta actually had relatively progressive labour legislation prior to 1948. The province's Liberal government was the first in North America to pass minimum wage legislation in 
1917. In addition, it was among the first provinces to establish its own industrial disputes machinery after the Judicial Committee of the Privy Council (the supreme appellate body at the time) ruled in 1925 that labour relations fell under provincial jurisdiction. The Labour Disputes Act, passed in 1926 by the United Farmers of Alberta government, permitted strikes or lockouts prior to conciliation. During the early thirties, the UFA also passed the Industrial Standards Act to provide a vehicle for legally binding negotiated wage rates on an industry-wide basis determined by conferences of employer and employee representatives.

This liberal approach to labour legislation continued in the early years of the Social Credit regime after 1935. In 1936 the Hours of Work Act was passed establishing maximum hours of work and a Board of Industrial Relations to administer the various employment standards statutes. A year later the Aberhart government passed legislation, based on the Trades and Labor Congress's model Freedom of Trade Union Association Act (FTUAA), that advanced union rights somewhat by recognizing the right of workers to organize and making it an offence for employers to discriminate against union members. And in 1938, responding to an Alberta Federation of Labour request to enact legislation compelling employers to recognize and negotiate with unions representing its workers, it passed the Industrial Conciliation and Arbitration Act (ICAA) to replace the FTUAA and the Labour Disputes Act and to require employers to bargain with representatives chosen by a majority of its employees. Further enhancements followed in 1944 when employers were required to deduct union dues when requested to do so in writing by an employee (Fudge and Tucker, 2001: 123, 141, 190, 202, 220-221; Geddes, 1990: 24-29, 40-42, 46, 48, 50$62)$.

While early Social Credit had a left populist strand that generated some relatively progressive policies, this disappeared by the post-war period. Ernest Manning, who succeeded William Aberhart as premier in 1943, was a rabid anti-communist who equated trade unionism with communism. In 1947 the government passed the Alberta Labour Act as a piece of housekeeping legislation to consolidate existing labour statutes. Minor revisions included formalizing the procedure for certifying bargaining agents. A year later, however, the Act was completely rewritten in response to labour unrest that Manning feared would shake investor confidence in the emerging energy industry. The 1948 amendments contained significant increases in the penalties for unions and union leaders who defied the conciliation and arbitration processes in the Act, including dissolution of collective agreements in cases where a judge ruled that a strike was illegal. In addition, union organizing was made more difficult by a provision that made it necessary for organizers to have an employer's permission to recruit members on his or her premises (Finkel, 1988: 134-135; Caragata, 1979: 140-141; Geddes, 1990: 98-101; Statutes of Alberta, 1947; Statutes of Alberta, 1948). 
This legislative regime, combined with a generally passive labour movement that was unwilling to challenge the government or employers, created a virtually strike-free province during the 1950s. Nonetheless, Manning and the Socreds made an already draconian labour law even worse in 1960 with the first amendments to the Alberta Labour Act since 1948. Information picketing outside an employer's premises for the purposes of union organizing was banned, and unions that used such tactics were denied certification. Members of the medical, dental, architectural, engineering and legal professions were prohibited from unionizing, as were employees who performed supervisory functions or had a confidential relationship with management. For those who could unionize, the strike weapon was further weakened by a prohibition against job action to protest the hiring of non-union employees, a ban on secondary picketing, and a provision allowing the Minister of Labour to end a strike if life or property was endangered.

While the labour legislation that developed from the 1920s to the 1960 s covered workers in the private sector and parts of the broader public sector, employees of the government and crown agencies were not covered by any collective bargaining legislation and therefore did not have the right to unionize. The Civil Service Association (CSA), a voluntary organization of provincial public servants formed in 1919, conducted informal discussions with the government regarding the terms and conditions of employment for its members, but the government was free to ignore any advice the CSA offered. Amendments to the Public Service Act in 1968 made the CSA the sole bargaining agent for direct employees of the provincial government but the employer retained the right to determine which items were negotiable and, in the case of a dispute, the employer could impose a settlement. Employees of crown agencies that were governed by governmentappointed boards did not have the right to unionize either. During the same year the CSA acquired bargaining rights for all employees of government boards and agencies. In contrast to the Public Service Act, the Crown Agencies Employee Relations Act (CAERA) provided mediation and binding arbitration mechanisms for the resolution of disputes. The passage of CAERA, however, effectively removed the right of employees of Crown agencies to organize and bargain collectively under the relatively more liberal Alberta Labour Act.

Peter Lougheed's Progessive Conservative government was elected in 1971 promising a more urbane and sophisticated approach to public policy, with an emphasis on activist province building, but its labour relations policy was indistinguishable from that of the ostensibly more reactionary Socreds. The Public Service Employee Relation Act (PSERA) of 1977, which merged and updated the CAERA and the collective bargaining section of the Public Service Act, did provide a modern system of labour relations for the Alberta public service by establishing a system for certification of bargaining agents under 
the newly formed Public Sector Employee Relations Board, including definitions of unfair labour practices found in other labour statutes. The Act banned strikes in favour of a system of compulsory and binding arbitration for all government and crown-agency employees covered by the legislation, however. In addition, such matters as work organization, assignment of duties, appointment and promotion, training and termination of employment were deemed non-arbitrable. And steep penalties were established for unions and individuals who violated the Act. Despite a ruling by the United Nationsaffiliated International Labour Organisation (ILO) that the PSERA's blanket prohibition on the right to strike violated the ILO's Freedom of Association and Protection of the Right to Organise Convention, which Canada ratified in 1972 with unanimous provincial consent, the Lougheed government refused to amend the legislation (Finkel, 1988: 142149; Statutes of Alberta, 1968a; Statutes of Alberta, 1968b; Statutes of Alberta, 1977; Panitch and Swartz, 1993: 49; Lowe, 1978; International Labour Organisation, 1977). ${ }^{2}$

\section{The Origins of University Faculty Collective Bargaining in Alberta}

The Canadian Association of University Teachers (CAUT) was a party to the complaint that prompted the negative ILO ruling on PSERA. CAUT was particularly concerned that the legislation specifically excluded academic staff from its ambit while also excluding this group of employees from the provisions of the Alberta Labour Act. This meant that after PESRA came into force in 1977, there was no statutory provision for academic staff at the four Alberta universities (as well as the province's colleges and technical institutes) to organize and bargain collectively. ${ }^{3}$

Prior to 1977 academic staff were eligible to acquire collective bargaining rights under the Alberta Labour Act, although this was not entirely clear in law nor was it ever tested. In 1962 the National Union of Public Employees applied to the Board of Industrial Relations (BIR) for certification of a bargaining unit of caretakers at the University of Alberta's Calgary campus. The BIR rejected the application on the grounds that the University Act vested the university's Board of Governors with final authority for determining the terms and conditions of employment of its staff and hence could not be compelled to enter into a collective bargaining relationship. While this would seem to suggest that the Board of Governors could not enter into any employment contracts, which was clearly absurd, and despite the fact that the decision was contrary to an earlier Supreme Court of Canada ruling on a similar issue, it was upheld by the Supreme Court of Alberta on judicial review. The Universities Act was subsequently amended to exclude non-academic staff from the Alberta Labour Act and to place them under the Public Service Act in 1967 and then to

\footnotetext{
${ }^{2}$ In the Labour Conventions case of 1936, the Supreme Court of Canada was evenly split on the question of whether the Canadian government had the power to pass legislation in areas of provincial jurisdiction in order to conform to ILO conventions that the federal government had ratified. The Judicial Committee of the Privy Council, on appeal, ruled that Canada did not have this power (Geddes, 1990: 90-91).
}

${ }^{3}$ The first draft of PSERA included academic staff within its ambit, but these references were removed between the first and third readings (Lowe, 1978: 11). 
transfer them to the Crown Agencies Employee Relations Act when the latter statute came into effect in 1968. This presumably left university academic staffs within the ambit of the Alberta Labour Act (Adell, 1974: 22-31).

Academic staff at Alberta universities never took the opportunity to apply to the Board of Industrial Relations for certification, however. Rather, faculty associations at the universities of Alberta, Calgary and Lethbridge chose to enter into "Special Plan" bargaining arrangements with their respective governing boards outside of the Alberta Labour Act. The Association of Academic Staff of the University of Alberta (AASUA) bargained informally with the university's Board of Governors from the 1950s. In 1966, the Faculty Handbook was amended to reflect that AASUA had the right to negotiate many of the terms and conditions of employment of faculty members and to conclude a written agreement with the governing board regarding annual salary scales. In 1969-70 and 197071, however, the board imposed salary-scale settlements following bargaining impasses, prompting the faculty association to consider unionization and certification. Rank-and-file support for such an approach was hostile or lukewarm, however, so in 1971 the association and the employer signed an agreement providing for final offer selection arbitration as the ultimate dispute resolution mechanism governing salaries and benefits negotiations (Tudiver, 1999: 93; Adell, 1974: 5, 61-72, 134; Unger, 1978). ${ }^{4}$

Prompted by these developments in Edmonton, the University of Calgary Faculty Association (TUCFA) began discussing and exploring the possibility of seeking recognition as the bargaining agent for its members. A survey conducted by the association in 1972 revealed that $90 \%$ of the membership rejected the status quo in which the governing board determined salary adjustments unilaterally, 60\% supported certification under the Alberta Labour Act, and a respectable 57\% wanted the right to strike. Subsequent membership votes in 1973 directed the association executive to seek union recognition. Apparently believing that certification was not possible without further provincial legislation, the association entered into a voluntary recognition agreement with the governing board outside of the act. In 1975 the parties signed their first "Agreement to Bargain Collectively," which allowed for negotiations on salaries and benefits with conventional interest arbitration as the ultimate dispute resolution mechanism.

At the University of Lethbridge, meanwhile, the parties followed the University of Alberta example and negotiated an agreement that included final offer selection arbitration for salaries and benefits. Amendments to the Handbook (contract language) were by mutual consent.

While these written agreements were an improvement over previous arrangements, they fell far short of the powers and protections that would flow to academic staff from

\footnotetext{
${ }^{4}$ Final offer selection is a form of interest arbitration in which the arbitrator is forced to choose one of the two proposals from the parties in their entirety. The arbitrator is not able to fashion his or her own award as is possible in traditional interest arbitration.
} 
certification under the Alberta Labour Act. At the University of Alberta, for example, the Faculty Handbook that was negotiated between the AASUA and the Board of Governors formed part of all faculty members' individual employment contracts and as such was binding under common law on all affected employees as long as the individual contracts did not contain terms that were inconsistent with those in the handbook. However, this agreement did not preclude individual faculty members from negotiating modifications or enhancements of their individual contracts with their employer, regardless of what was in the handbook. The faculty association was powerless to object legally to such individual arrangements in the absence of a separate agreement between itself and the governing board specifying that the employer would not enter into individual employment contracts with association members that were inconsistent with the Faculty Handbook. In contrast, if the AASUA had certified under the Alberta Labour Act it would have been the sole bargaining agent for its members and individual bargaining would not be possible.

Furthermore, the Board of Governors was not compelled to bargain with the faculty association regarding changes to the Faculty Handbook. The board had the legal right to refuse to bargain and there was nothing that the AASUA could do about it short of acquiring bargaining rights under the Alberta Labour Act. Similarly, neither the separate agreement regarding the negotiation of annual salary scales that provided for final offer selection arbitration nor the terms of a Selection Officer's awards were binding on the parties in the absence of union certification. But the parties explicitly stated in their salaryscale negotiating agreement that the AASUA was not a "trade union" and the Board of Governors was not an "employer" as understood by applicable labour legislation. In other words, the agreements governing relations between the association and the board were meaningless other than as statements of good faith. The legal status of the agreements at the universities of Lethbridge and Calgary were the same (Friedmann, 1973; CAUT Bulletin, 1973; Vanderberg, 1978; Lowe, 1978). ${ }^{5}$

At Athabasca University, meanwhile, the faculty association was not organized until 1977 at a time when the university itself was making the transition from interim to permanent status. At that time all non-executive staff members (professional--including faculty--and support) at the university were members of the Athabasca University Staff Association, which was a voluntary organization registered under the Societies Act. A Staff Handbook existed covering the terms and conditions of employment of all staff. Although the staff association was mentioned in the handbook, it was not a party to the agreement. And, indeed, as legal counsel for the employer warned, the document was an overlapping amalgam of policy, procedure and terms of employment, some of which could be considered part of individual employment contracts and some of which could not.

Once Athabasca University became a permanent entity in 1978, the Athabasca University

\footnotetext{
${ }^{5}$ A number of other faculty associations in the country chose special plan arrangements rather than avail themselves of the certification procedures under labour legislation, including associations at the University of Toronto and the University of British Columbia (Roydhouse, 1978; Smith, 1978).
} 
Faculty Association (AUFA) and the Athabasca University Governing Council (AUGC) negotiated a collective agreement covering the terms and conditions of employment for its members. While its sister associations had deliberately opted not to seek the union certification to which they were entitled when they entered "Special Plan" agreements with their respective employers prior to 1977, the only option available to AUFA after PSERA's proclamation was to seek voluntary recognition in the absence of a statutory collective bargaining framework. The agreement AUFA and AUGC negotiated in 1978 mirrored the academic staff agreements at the universities of Alberta and Lethbridge, including the provision for final offer selection arbitration (Athabasca University Faculty Association, 1977; Athabasca University Interim Governing Authority, 1977a and 1977b). The statutory limbo ended unsatisfactorily for academic staff in 1981 when the Universities Act was amended to include references to collective bargaining. The act named the faculty associations at the four provincial universities as the bargaining agents for academic staff and compelled the respective governing boards to bargain terms and conditions of employment with them. The right to strike existed in theory since the act stipulated that, in the absence of an alternative dispute resolution mechanism, binding arbitration would be read into collective agreements. Hence, parties could conceivably freely negotiate strike or lockout provisions. In practice, however, since all four associations were party to existing agreements that contained binding arbitration provisions, it was highly unlikely that employers would voluntarily agree to modify these arrangements in favour of strike/lockout. And, indeed, the intent of the PSERA was to deny the right to strike to academic staff as well as other public-sector workers.

Furthermore, the Act gave employers the extraordinary power to unilaterally determine membership in academic staff bargaining units and hence in the respective faculty associations. Employers were empowered to "designate" academic staff and all staff so designated were members of the academic staff association. Employers could also "dedesignate" individual staff or groups of staff. This of course was contrary to the norm in North American labour law, where third-party labour boards are empowered to determine appropriate bargaining units (Statutes of Alberta, 1981).

In addition, since academic staff continued to be excluded from the PSERA, the Alberta Labour Relations Act (which replaced the Alberta Labour Act in 1980), and access to the Alberta Labour Relations Board (successor to the Board of Industrial Relations), the standard remedies available to parties to a collective agreement were not available to them. Under the PSERA or the Alberta Labour Relations Act, for example, a bad-faith bargaining complaint would be made to the labour board where it would be heard by knowledgeable arbiters and would result in a relatively quick judgment. Under the Universities Act, however, such a charge would either have to be taken to the Court of Queen's Bench, which is prohibitively expensive and where the chances of facing a judge with labour-law 
experience are rare, or processed through the lengthy grievance procedure process if the relevant collective agreement contains specific language compelling the parties to bargain in good faith. Both avenues are ill-suited to the quick, easy and relatively inexpensive resolution that is required to facilitate effective collective bargaining. Furthermore, the courts are likely to impose the common-law remedy of financial damages rather than to compel the parties to change their behaviour.

During the 1970s faculty associations across the country were seeking collective bargaining rights. In all other provinces, academic staff were covered by the main labour statutes allowing them to follow the normal route to certification and union recognition by filing applications with their respective labour boards. First contracts, including the right to strike, were then normally negotiated. By the middle of the 1980 s over fifty percent of university faculty in Canada were unionized on twenty-nine campuses and "special plan" arrangements (where faculty negotiated without seeking union certification) were in place on a further eleven campuses (Tudiver, 1999: 93-94).

Hence, it is reasonable to assume that one or more of Alberta's faculty associations would have made the transition from uncertified to certified bargaining agent if the statutory regime that existed in other Canadian provinces had continued to be available to them after 1977. The case of Manitoba's Brandon University is instructive. The Brandon University Faculty Association bargained with its governing board for eight years in a voluntary relationship without seeking union certification. When it appealed to the Manitoba Labour Relations Board in 1977 for a ruling on the inclusion of instructional associates in its bargaining unit, the board ruled that since the association was not a certified union it did not have legally enforceable bargaining rights. A year later the association conducted an organizing drive, was certified as the legal bargaining agent, and concluded a "first contract" with the employer, including the right to strike (Black, 1979: 15). In the absence of this avenue, however, Alberta's university academic staff are stuck with compulsory interest arbitration.

\section{Compulsory Interest Arbitration in Practice}

Compulsory interest arbitration is well established in Canadian industrial relations. While it has a long history, its use increased substantially with the wave of public-sector unionization in the 1960s and 1970s. Various governments have used their unilateral authority to deem groups of their employees as "essential," subject them to compulsory arbitration for the resolution of bargaining disputes, and thereby deprive them of their right to strike. Most jurisdictions have deemed police and firefighters to be essential. In some cases public authorities have gone further and designated whole swaths of the civil service as "essential" and subject to compulsory arbitration. Alberta is the most extreme case, where the right to strike is denied to all workers who are subject to the PSERA. In the 
federal public service, meanwhile, employee groups may choose compulsory arbitration or strike/lockout as dispute resolution mechanisms at the beginning of bargaining. ${ }^{6}$

Faculty associations and governing boards in Alberta resorted to arbitration regularly during the 1970s. The parties at the University of Alberta went four times between 1971 and 1978, while in Calgary the parties went in each of their first three years of bargaining between 1975 and 1978 (Unger, 1978: 13; Vanderberg, 1978). Most bargaining disputes in the 1980s and 1990s were settled through negotiations, however. During that time Athabasca has gone to arbitration four times (1984, 1985, 1993 and 2003), Calgary three times (1991, 2001 and 2002), Alberta twice (1991 and 2000), and Lethbridge once or twice in the 1980s and again in 1993. The arbitrations at Athabasca, Lethbridge and Alberta were limited to salaries and benefits, with Calgary referring a broader range of issues to arbitration panels.

Athabasca's two arbitrations during the 1980s revolved around the university's relocation from Edmonton to Athabasca in 1984. The central issue in the 1985 dispute was comparative living costs in Edmonton and Athabasca. The faculty association argued that the cost of living was five to eight percent higher in the new location and hence asked for a salary increase that was $1.2 \%$ higher than the governing council was prepared to give. In addition, the association asked for a modest increase in the professional development fund. Gerard Hawco, the selection officer, chose the employer's position. He reasoned that the most relevant factor in seeking to replicate what would have happened if bargaining had been allowed to run its normal course (to strike or lockout) was comparability with relevant freely negotiated settlements. The association conceded in its brief that its salaries were comparable to those at the other three universities in the province. Hawco accepted that there was some merit in the association's argument regarding living costs, but it was not strong enough to convince him that it should trump the comparability test. He claimed that he would have awarded a settlement slightly higher than the employer was offering if he had had the freedom to craft his own agreement (which he did not under final offer selection), but this was small consolation for the members of the faculty association (Hawco, 1985).

\footnotetext{
${ }^{6}$ Interest arbitration is primarily a public-sector phenomenon and there are differing views on its efficacy and necessity in this sector. Many trade unionists view interest arbitration as an unjustified curb on workers' fundamental and inherent right to strike. Most written commentary on the subject, however, comes from industrial relations practitioners and specialists who are part of what might be described as a liberal consensus that accepts the legitimacy of unions, collective bargaining, and the reality of strikes (though not workers' inherent right to strike). Within this liberal consensus, there are debates about the extent to which strike action should exist in the public sector, the potential "chilling" and "narcotic" effects of arbitration on bargaining, and the problems of legally trained third parties making decisions on complicated economic issues, among other matters. An accessible and thorough survey of these issues from a critical liberal perspective remains (See Weiler, 1980: especially chapter seven). Other perspectives on interest arbitration include McCallum (1990); Weiler (1981); and Jackson and Teplitsky (1998).
} 
Associations and governing boards at all four universities went to arbitration in the early 1990s. Awards are available for Alberta, Lethbridge and Athabasca. Alberta was the first in 1991. Inflation in Edmonton was running at close to seven percent that year. The faculty association sought a combination percentage and lump-sum increase to base salaries that it estimated amounted to a total increase of six percent. The employer claimed that the association's proposal would cost $8.48 \%$. The employer, meanwhile, was offering a package that it claimed amounted to a $6.56 \%$ increase. The crux of the disagreement was differing approaches to calculating the costs of the proposals. The employer maintained that the "total compensation base" should be calculated in arriving at the costs of the respective proposals. This included salaries, pensions, benefit plans and merit increments, but did not include Canada Pension Plan and Unemployment Insurance premiums. The association's proposal, in contrast, was concerned only with salary increases. Hence the substantial discrepancy between the employer's and association's costing of the association's proposal.

The employer presented evidence that the association had accepted the "total compensation base" concept during bargaining, only to abandon it in its final offer to the selection officer. The officer accepted this evidence (while conceding that merit increments should not be included in the calculation of annual total compensation), noted that comparability was the most important criterion in determining awards, and chose the employer's position. He claimed, as Hawco had in the 1985 Athabasca arbitration, that he would have fashioned an award somewhere between the two positions if he had had the authority to do so (Taylor, 1991).

At the University of Lethbridge in 1993 the employer was seeking an agreement that was of lesser value than the freely negotiated settlements at the universities of Alberta and Calgary that year. It claimed that it could not afford the increased benefits costs that were part of the faculty association's proposal. In choosing the association's offer, the selection officer noted that the award was comparable to what had been negotiated at Alberta and Calgary. Furthermore, he noted that it was not his job to "second guess" how the governors of the university should deal with its budgetary problems or whether the association was wise to risk possible staff reductions by going to arbitration (Jones, 1993).

In October of the same year Allen Ponak presided over a final offer selection at Athabasca University in which the main unresolved issue was benefit costs. Both parties agreed that salaries should not be increased. The employer, however, demanded a benefit cap that would ensure that its financial contribution to the benefit plan would not exceed what it was on 1 July 1993, which the association rejected. The association also asked for a $\$ 350.00$ per member lump-sum payment in its final offer. 
While rejecting the association's claim for a lump-sum payment, Ponak ruled that the employer's demand for a benefit cap was unreasonable. He did accept that benefit caps were in place for academic staff at the universities of Lethbridge and Calgary as well as for support staff at Athabasca. He noted, however, that these caps were different than the one being proposed in the current arbitration. In the Calgary, Lethbridge and Athabasca support-staff cases, benefits were capped at the end of the collective agreements (30 June 1994). Athabasca's governing council, in contrast, was demanding a cap at the beginning of the collective agreement. The association argued that if the employer's position was accepted, it would result in an immediate reduction in salaries for its members since benefit premiums had been raised since 1 July 1993. In making his decision in favour of the association, the selection officer accepted that this would be unfair in comparison with the other academic staff agreements that contained benefit caps. Since he was forced to choose one package or the other in its entirety in this final offer selection process, Ponak chose the association's position (including the $\$ 350.00$ payment), arguing that the benefit cap issue was the more important one (Ponak, 1993).

It remains a mystery why AUGC forced this issue to arbitration. It claimed that it needed a benefit cap to force the association to bargain seriously about benefits. In fact, the collective agreement between the parties contained a letter of agreement from 1983 that specified how benefits were to be considered in bargaining. The letter included a formula that arrived at the value of increases or decreases in benefits costs during a given year as a percentage of total compensation, and stipulated that this calculation was to be applied to the salaries and benefits settlement in the subsequent year's negotiations. In other words, ten years prior to the benefit cap arbitration the parties had agreed that changes in benefits costs would be discussed in negotiations and would form part of settlements. Nonetheless, the governing council threatened layoffs and bullied the association into accepting benefit-cap language in its collective agreement in the 1994 negotiations. The employer insisted on the continued inclusion of this language in the agreement at every subsequent round of negotiations until 2004, even though it clearly contradicted the letter of agreement (Athabasca University Faculty Association and Athabasca University Governing Council, 2002; Taylor, n.d.).

The university labour relations climate was quiet during the balance of the 1990s. By the end of the decade, however, academic staff members were restless to recoup some of the losses they suffered as a result of the Klein rollbacks of the early 1990s. The province was enjoying substantial surpluses, even with the niggardly economic rents the province charged for its resources in comparison with other energy-rich jurisdictions. Even so, the government was continuing to resist demands to restore funding in education, health and other public services to levels that existed prior to the cuts. Funding to universities did not keep pace with inflation, causing pressures on salaries and other budgetary items. Alberta 
faculty salaries, once the best in the country, fell steadily during the decade. ${ }^{7}$

It was in this context that faculty associations at three of the province's four universities were forced to arbitration between 2000 and 2003. TUCFA went twice while AUFA and AASUA each went once. Salaries were the main issues in all four, although TUCFA and the University of Calgary governors placed a variety of monetary and non-monetary issues before their arbitration boards. ${ }^{8}$ The employers won all four arbitrations. Edmonton lawyer Andy Sims was the selection officer in the Alberta and Athabasca cases. Sims also chaired one of the Calgary panels, while Calgary lawyer David Jones chaired the other one.

The issue that took the AASUA to arbitration in 2000 was wage comparability with other large research universities in the country. Both the employer and the association agreed in bargaining that the University of Alberta's salaries should reach the 75th percentile of the "G-10" universities in Canada (large research institutions such as University of Toronto, University of British Columbia and Queen's University). The disagreement was over how quickly to get there. Both parties proposed a two-year agreement, with the employer offering $4.0 \%$ and $3.75 \%$ for faculty (slightly more for professional staff) and the association countering with $5 \%$ for all members in each of the two years. Neither proposal would move the salaries to the agreed level over the two years, but the employer's proposal would result in a longer period of time before the goal was achieved. Both parties relied on Statistics Canada salary data that showed that University of Alberta salaries were indeed well below those of national comparator institutions.

The employer maintained it did not have an inability to pay, but then went on to argue it could not afford the association's proposal! It pointed to a modest $2.75 \%$ increase in its base operating grant from government. As a result, it would incur a $\$ 3$ million deficit even if its own salary offer was accepted by the arbitrator. It claimed that in order to fund the association's proposal, it would have to "tax back" expenditures from various university departments resulting in further cuts to the services on which AASUA members and other members of the university community relied.

Sims bought the employer's dubious argument that it could afford the association's proposal but really it could not. He noted that both proposals were higher than most of the relevant provincial comparable settlements and exceeded the settlements in comparable Canadian universities. The latter is unsurprising given that the whole point of the agreed exercise was to begin to close the gap between the University of Alberta and its national

${ }^{7}$ For the general impact of the Klein cuts on Albertans, see Harrison and Laxer (1995) and Lisac (1995).

${ }^{8}$ As mentioned earlier, TUCFA and the Calgary governors negotiated an agreement in 1975 that limited arbitral matters to salaries and benefits. After the 1981 Universities Act amendments this was re-negotiated to subject all parts of the collective agreement to interest arbitration (Snow, 1983a; 1983b). 


\section{Compulsory Arbitration and the Right to Strike: \\ The Experience of Alberta's University Faculty}

comparators. Sims went on to argue that the "University (sic) cannot simply deficit finance, so any money must be taken from other current priorities." This points to the crux of the ability to pay question in public-sector interest arbitration, however. The University of Alberta was forced to deficit finance in order to even hope to maintain salaries and services comparable to other universities of its size in the face of government grants that were clearly inadequate. The real issue was the fact that the provincial government was providing inadequate funding to universities and was indirectly forcing university employees to bear the resulting costs (Sims, 2000).

In 2001 TUCFA exercised its right to reopen a two-year agreement after the first year in order to address salary and other issues. The parties held three short bargaining sessions before moving to arbitration because, according to TUCFA, "it was clear that we were too far apart to reach an agreement." The association proposed a variety of issues for resolution, many of which the panel deemed to be beyond its mandate. Besides some benefits enhancements, the key TUCFA demand that the panel was empowered to entertain was a $15 \%$ increase to salary and increment values as well as a $\$ 2500$ across-the-board increase. The employer countered with a $\$ 2500$ across-the-board increase (costed at $3.3 \%$ ) and minor increment increases costed at $0.2 \%$.

The Calgary parties, like their counterparts in Edmonton a year earlier, recognized that academic salaries at their institution were becoming increasingly uncompetitive. The governors claimed they were committed to moving the University of Calgary back to within the top quarter of average salaries among the major research universities in the country. It would take fifteen years to do so, however, because of meagre government grants and various limits on their ability to raise student tuition. To fund a salary increase larger than the governors were offering, they claimed, would require the reallocation of resources from other equally important priorities.

The faculty association did not dispute the fact that the university was in a difficult financial position, but it argued that paying competitive academic salaries was more important than the other priorities the governors identified. Moreover, it went on to assert that the real issue was government underfunding of post-secondary education and to suggest that the real dispute was not between the two parties at the bargaining table but between the two parties and the government. The government "is part of this conversation," it claimed, and therefore should be at the bargaining table.

While a reasonable observer might agree with this proposition, what is its merit in presenting a case to an arbitration panel? The association advanced the rather unorthodox argument that the arbitration process, notably the eventual award, should be used to send a message to government that university funding was inadequate. It began by claiming 
that it did not have a place in the governors' meetings with government officials and that its only voice was through the arbitration process. ${ }^{9}$ The crux of its position, however, was that the provincial government had established the whole system in which the parties operated, from the legislation establishing the bargaining relationship through tuition-fee regulations to its base and discretionary funding decisions. This was the essence of the association's case and it declined to counter evidence presented by the governors showing that recent salary increases at Calgary were comparable to increases at other Canadian universities. TUCFA simply responded that it was necessary to "break out of the mold."

While conceding that there was considerable merit to the ghost at the bargaining table accusation, the majority of the arbitration panel did not accept the political role TUCFA was proposing for it. Geoff England, the faculty association's nominee on the panel, offered a spirited dissent, however. He argued that the replication principle that supposedly governs interest arbitration is moribund in the Alberta university sector. Since there is no strike/lockout provision in any faculty/board collective agreement, it is interest arbitrators rather than negotiating parties who determine the contours of comparability. "Today," England asserted, "arbitrators follow arbitrators... who follow arbitrators... who follow arbitrators." Interest arbitration, in this view, prevents collective agreement breakthroughs from occurring. In industries or jurisdictions where the strike/lockout mechanism exists, a significant change to the terms of one collective agreement will permeate through the rest of the industry by various means, including interest arbitration. In the absence of strike/lockout, however, "the worse off come up to the mean average and the better off do not get further ahead" as normally cautious and conservative arbitrators chase each other's tails.

Echoing TUCFA's contention that the provincial government established all of the parameters for faculty-board negotiations, but was absent from the bargaining table, England concluded that a salary increase of eight percent was justified; he claimed this would have sent a political message to the government without placing too severe a burden on the employer. The majority, however, chose to grant a $1.4 \%$ increase to the grid plus $\$ 2000$ per person across the grid (equaling about $4 \%$ plus $0.6 \%$ in benefits improvements) (Sims, Cassidy and England, 2001: 14, 21, 32-34 and passim.).

The Calgary parties were back at arbitration a year later as they attempted to conclude a new collective agreement. While the faculty association (renamed The Faculty Association of the University of Calgary) was seeking certain improvements to salaries and contract language, an aggressive employer was demanding contract concessions. Salaries, benefits, the definition of compensation, mandatory retirement, and the right to strike were the main unresolved issues.

9 TUCFA left the Confederation of Alberta Faculty Associations (CAFA) voluntarily in the mid1990s. CAFA's purpose is to provide a provincial voice for university faculty associations, including relations with the government. 
The faculty association proposed a salary settlement of nine and five percent over two years, while the governors countered with an offer of $3.25 \%$ and $3.5 \%$. The main comparator was the first two years of a freely negotiated three-year agreement at the University of Alberta, which provided for increases of $4.0 \%, 4.25 \%$ and $5.25 \%$ for academic staff and slightly higher for professional staff. The association argued that recruitment and retention was an issue for the university, that productivity had increased substantially and that University of Calgary salaries were low compared to the University of Alberta and other universities in the country. To support the last claim, it presented Statistics Canada data illustrating that mean and median salaries of its members ranked between 19th and 29th (depending on rank) among all universities in the country, regardless of size.

While agreeing that its academic salaries should be more competitive, the governors claimed that is financial position (government grants below inflation, the legislative requirement to balance its budget, and a legislative limit on tuition increases) dictated that the necessary salary adjustments could only occur over many years. They then proceeded to argue that, in fact, Calgary salaries were comparable to those at other universities in the country if mean and median data were ignored in favour of scale minima and maxima. Means and medians were misleading, they claimed, because not all universities comply with their legal obligations to report to Statistics Canada each year, various forms of supplementary compensation are not reflected in reported salary data, and there are significant differences in the distribution of academic staff members around the medians at different institutions. Scale minima and maxima, on the other hand, "are a measure of a university's ability to compete." The University of Calgary's salary scales were between fourth and eighth in the country depending on rank, according to the governors, and their ability to hire upscale and offer market supplements allowed them to deal with specific recruitment and retention issues.

David Jones, the chair of the arbitration board, accepted that the first two years of the University of Alberta settlement was the relevant comparator and therefore the most important consideration in determining a salary award in this case. But comparability did not mean identity, he said, in awarding salary increases of $3.5 \%$ and $3.75 \%$. He accepted the employer's unfounded assertions that Statistics Canada salary data were unreliable and that scale minima and maxima were more appropriate comparators. Hence a salary adjustment higher than the University of Alberta settlement was not justified. But Jones went further in concluding that the absence of a mandatory retirement policy and supposedly greater restrictions on the use of sessional instructors at the University of Calgary meant that an award of $1.25 \%$ less than the settlement at the sister Alberta university was warranted. 
After giving the governors essentially what they wanted on salaries, Jones accepted the substance of their proposal on benefits as well. The governors had proposed that increases in the costs of benefits should be shared equally (50/50) between the governors and academic staff members as of 1 July 2001. The association countered that the governors should continue to pay $100 \%$ of the benefits for the life of the agreement. Jones imposed the equal cost-sharing formula as of 1 July 2002.

The governors also used this interest arbitration to reverse a rights arbitration award on the definition of compensation. During the term of the previous collective agreement, Arbitrator Ish (a Saskatchewan-based arbitrator) upheld an association policy grievance that supplementary compensation that some members received from the Alberta Heritage Foundation for Medical Research violated the association's exclusive bargaining rights. In bargaining and in its submission to the interest arbitration board, the governors sought to limit the items to be bargained between the governors and the association to salary scales, increments, overload remuneration, market supplements and benefits, and to exclude administrative honoraria, research prizes and research stipends. Jones, echoing comments Sims made on the same subject in the 2001 Calgary award, overturned Ish by changing the definition of "rank salary" in the collective agreement from "....and does not include honoraria or other salary modifiers..." to "... and does not include administrative honoraria, research stipends and research prizes (such as AHFMR prizes), or other salary modifiers paid by the University." Jones, like Sims before him, argued that if the collective agreement was silent with respect to a specific form of compensation (such as AHFMR prizes), this meant that the parties had agreed to leave these items to the employer's discretion.

The employer also asked the arbitrator to include mandatory retirement in the collective agreement. The University of Calgary is the only university in Alberta that does not have a mandatory retirement article in its academic staff collective agreement. The university had a mandatory retirement policy for academic staff from 1965 to 1985 . When section 15 of the Canadian Charter of Rights and Freedoms came into effect in 1985, the Alberta government passed omnibus legislation amending the mandatory retirement provision in the Universities Academic Pension Plan, changing the definition of age in the Individual's Rights Protection Act (IRPA) to mean eighteen years or older, and amending the IRPA to allow discrimination that is "reasonable and justifiable in the circumstances." In response, the University of Calgary adopted an interim policy that allowed employment passed sixty-five. At the University of Alberta, meanwhile, Olive Dickason filed a human rights complaint against her employer charging discrimination on the basis of age when she was forced to retire at age sixty-five under the provisions of the academic staff collective agreement. Dickason's complaint was upheld by a Board of Inquiry and the Court of Queen's Bench. In response to the Court of Queen's Bench ruling, the University of 
Calgary abolished its mandatory retirement policy. The Governors of the University of Alberta were ultimately successful at the Alberta Court of Appeal and the Supreme Court of Canada, however, in arguing that mandatory retirement was "reasonable and justifiable in the circumstances" and having the Dickason decisions overturned.

The Calgary governors contended in their brief and in arguments to the Jones arbitration board that they were at a disadvantage in the Alberta and Canadian markets because of the absence of mandatory retirement at their institution. Besides the other Alberta universities, twenty "major" universities outside of the province had mandatory retirement in policies or collective agreements. They claimed, without offering evidence, that those institutions with mandatory retirement enjoyed a financial benefit as a result of their ability to replace more highly paid senior professors with junior professors just beginning their careers. At their own institution, they argued, mandatory retirement would result in a cost saving of between $\$ 4.9$ million and $\$ 7.2$ million during the life of the collective agreement if between zero and fifty percent of the seventy senior professors who would reach sixty-five during that time were replaced by junior faculty. By contrast, matching the settlement at the University of Alberta would cost an additional \$1.9 million over the two years of the agreement.

The faculty association took the view that it would be improper to effect such a significant change to the collective agreement through interest arbitration. Any such change should be freely negotiated and not imposed. In addition, the governors were free to reintroduce a mandatory retirement policy if they wished. Furthermore, it claimed that the Dickason case dealt with different matters of fact and was decided in a different social and economic context. Citing a 2001 British Columbia Court of Appeal decision urging the Supreme Court of Canada to reconsider mandatory retirement, the association suggested the court might uphold a similar challenge today. Finally, it questioned the governors' claim of significant financial savings through mandatory retirement. Members eventually retire, sooner rather than later normally, and previous early retirement schemes were successful in reducing the university's salary costs.

The arbitration board chose not to insert a mandatory retirement article in the collective agreement. The chair concluded that it would not be appropriate to effect such a change through interest arbitration. He noted that for the twenty years prior to 1985 mandatory retirement had existed as a policy of the governors rather than as part of the collective agreement. Furthermore there was no evidence to suggest that the absence of mandatory retirement had had an adverse effect on the university's tenure and evaluation systems or that staff members over the age of sixty-five were not competent. On the contrary, members of the university's senior administration had stated publicly on more than one occasion that the absence of mandatory retirement was of assistance in their recruitment 
and retention efforts. Jones did accept the employer's argument that the University of Calgary suffered a competitive financial disadvantage by not having mandatory retirement, however. While conceding that "[i]t is difficult to quantify how much higher the salaries could be at the University of Calgary if it had a mandatory retirement requirement," his salary award was remarkably close to the governors' position.

The final major item that the board was asked to arbitrate was the faculty association's proposal to add a strike option to the article governing dispute resolution. Noting that the strike option was available in most academic staff association collective agreements in Canada and that strikes were lawful under the Universities Act, the association argued that a strike option was consistent with the replicative approach in interest arbitration. The governors countered that the association's duties and responsibilities that flowed from the Universities Act made the strike option inappropriate. First, the association was automatically the bargaining agent for academic staff and was not required to seek certification. Second, members had no option to choose a different bargaining agent. Third, the Universities Act made no provision for management exclusions from the bargaining unit, a supervising labour board, votes on offers, conditions under which strikes and lockouts could be permitted, and other matters covered by labour relations codes. Jones, with the concurrence of the employer nominee, chose not to alter the collective agreement to allow strikes. In dissenting from the majority decision, the association's nominee noted that interest arbitration was designed to replicate the collective bargaining process, Alberta faculty associations had the legal right to strike, and the only way this legal right could be reflected in collective agreements was through an interest arbitration award (Jones, Neuman and Kanee, 2002: 11, 30 and passim.; Governors of the University of Calgary, 2002).

AUFA was also forced to arbitration in 2002 to resolve a dispute with AUGC. The AUFAAUGC collective agreement distinguishes between salaries and benefits bargaining and "terms and conditions" (contract language) bargaining. Final-offer-selection compulsory arbitration is the ultimate dispute resolution mechanism governing the former, and the latter is subject to a "stonewall clause" whereby the status quo prevails unless and until both parties agree to a change in language. In the 2002 salaries and benefits negotiations, the parties agreed to all items except the appropriate salary settlement for 2002-2003 and 2003-2004. AUGC submitted a final salary offer of $4.0 \%$ and $4.25 \%$ to the selection officer while AUFA submitted an offer of $5.0 \%$ and $5.5 \%$ for the years in dispute (Athabasca University Faculty Association and Athabasca University Governing Council, 2002; Taylor, n.d.) .

The parties had engaged in bargaining for eight months before reaching an impasse in October. At the time negotiations ceased there were two freely negotiated directly relevant 
comparators in the province. The first was the University of Alberta agreement covering the 2002-2005 period and discussed above. The second was an agreement at the University of Lethbridge for 2002-2004. The Lethbridge settlement was $2 \%$ plus $\$ 2000$ for 2002-2003 and 2.5\% plus $\$ 2000$ for 2003-2004, or a total percentage increase of about $11 \%$ (not compounded) over the two-year life of the agreement. The AUGC offer was the same as the first two years of the percentage increase for academic members of the AASUA (the increase for professional members was slightly higher), while the AUFA offer was slightly less than the total percentage increase for University of Lethbridge Faculty Association.

In bargaining, in its arbitration brief and in representations before the selection officer, AUFA argued in favour of comparability with the University of Lethbridge. The association conceded that Lethbridge was the appropriate comparator based on the jurisprudence. Both were primarily undergraduate universities operating under the same provincial funding and statutory regime. The other two universities in the province, in contrast, were research-intensive institutions with medical and professional faculties. There were two elements to the association's comparability argument. The first was the salary increases for 2002-2004. The association was proposing a salary adjustment that was closer to the Lethbridge settlement than to the other freely negotiated settlement at the University of Alberta. The second element was actual compensation levels. Even though it was not asking for catch-up in its offer, AUFA made a detailed argument using Statistics Canada data to show that the mean salaries of its academic members were below those in each and every comparator group, beginning with the University of Lethbridge but also including all universities in Canada, small undergraduate universities, universities in the Prairies, and other universities in Alberta. AUFA's offer, therefore, would ensure that the gap in salaries between Athabasca and Lethbridge would not become substantially greater, but neither would it become smaller members (Athabasca University Faculty Association, 2003).

The AUGC's main argument in support of its position was that it was constrained in what it could afford for academic salaries because of it ability to pay and because it had other priorities for the monies to cover the modest cost difference between the two settlements. In addition, it maintained that its offer was comparable to settlements for professional and academic staff at other universities in the province. It noted the University of Alberta academic staff settlement, but it also pointed to settlements in the four percent range for professional staff at other universities who were not part of academic staff associations. It claimed that because of the high proportion of professional staff in AUFA (about $43 \%$ at Athabasca compared to $17 \%$ at the University of Alberta and lower percentages at the other Alberta universities), proper comparators should include both academic staff and non-academic staff settlements. The association countered that the AUGC had the power 
under the Universities Act to designate professional and academic staff as "academic," and therefore members of the faculty association, and, in its wisdom, it had chosen to designate all professionals at Athabasca University as academic. AUFA suggested that in making this designation AUGC no doubt recognized that professional staff at Athabasca were more integrated into the academic function than professionals elsewhere because of its unique distance delivery model.

AUGC also maintained that Athabasca salaries were not lower than salaries elsewhere or, if they were, there were legitimate reasons for any differences. Borrowing an argument that the employer had made successfully at the University of Calgary, the council dismissed comparative Statistics Canada data on academic salaries as misleading and useless. Some (unnamed) university employers defied the law by not reporting regularly to the federal agency and, in some cases, the sample sizes were too small to make a comparison. Furthermore, Statistics Canada's organization of salary data by age, means and medians was found to be of little value to AUGC. More useful, it claimed, were factors such as years in rank and years of service. With little verifiable data to support this claim, the council asserted that Athabasca University salaries were competitive on these measures. Moreover, AUGC argued that scale minima and maxima were better indicators of comparative salaries than composite salary data, however organized, and that Athabasca University's scales were similar to scales elsewhere (Athabasca University Governing Council, 2003; Athabasca University Faculty Association, 2003).

Andy Sims, the selection officer, chose the AUGC position. He rejected the council's ability to pay argument, concluding that both final positions could be accommodated within the university's budget. But when he assessed the comparators he decided that the AUGC position was more reasonable than the AUFA position, although he implied in his award that he might have crafted a settlement somewhere between the two positions if the process had allowed him to do so. Although Sims did not dispute the association's costing of the University of Lethbridge settlement, he accepted the council's argument that its combination of a percentage increase and an across-the-board payment was designed to raise the salaries of assistant professors, which solved a problem that was unique to that university. Moreover, and contrary to one of the principles in the arbitral jurisprudence, he did not accept that the University of Lethbridge was the primary comparator for Athabasca University. Other universities in the province and, to a lesser extent, colleges in the province and universities outside of the province were proper comparators in his view. The most relevant freely negotiated university settlements, then, were at Lethbridge and Alberta. But Sims also included the recently arbitrated settlement at the University of Calgary among his comparators, which was surprising since the jurisprudence suggests that the purpose of interest arbitration is to replicate what would have been the result if the parties had conducted unfettered negotiations up to and including a strike/lockout if 
necessary. Including Calgary among the comparators, however, allowed the selection officer to conclude that AUGC's offer was the closer of the two to the average settlement in the sector (Sims, 2003).

What, then, do we make of these four arbitrated settlements? The AASUA and AUFA clearly "lost" since the employers' final offers were chosen in both cases. The Faculty Association of the University of Calgary won on some items and lost on others in its two arbitrations, but the awards on crucial issues such as salaries were closer to the employer's positions.

Arbitrators formally follow the principles established in the jurisprudence. They attempt to replicate what would have happened had a dispute proceeded to strike or lockout, give most credence to comparable settlements in the sector and, for the most part, discount employer ability to pay arguments. The evidence presented here, however, suggests that employer arguments are more likely to be accepted than association arguments unless the position the employer is advancing is patently unreasonable, arbitrators are willing to accept employer assertions in the absence of sound evidence, association breakthroughs are impossible but employer rollbacks are not, and conflicting lines in the jurisprudence are interpreted in the employer's favour.

Jones, at Calgary, for example, was not prepared to accept the employer's proposal to eliminate mandatory retirement. He noted that a mandatory retirement policy had existed in the past and the employer had the power to develop one in the future if it chose. Furthermore, employer representatives publicly touted the absence of mandatory retirement as an important recruitment and retention tool. But Jones, in the absence of sound evidence, accepted the employer's assertion that it suffered financially because it did not have a mandatory retirement policy. He then established an arbitrary value for that financial advantage that allowed him to make an award that was very close to the employer's offer.

Similarly, in the case of the reliability of Statistics Canada data, Jones at Calgary and Sims at Athabasca accepted employer assertions that these data were so unreliable as to be of little use and that scale minima and maxima were more appropriate measures of comparable salaries. AUFA, in its presentation to the arbitrator, noted that Statistics Canada data were internationally recognized for their reliability, that University of Toronto scales were among the lowest in the country yet their mean and median salaries were widely recognized as the highest based on Statistics Canada calculations, and that at other institutions such as the University of Alberta both parties agreed to use these data to determine comparability. But the doubts and questions raised by the employers were sufficient to allow the arbitrators to discount this evidence. 
Jones was also prepared to roll back association gains at Calgary on benefits and the definition of compensation. He introduced a 50/50 cost-sharing formula for benefits. More importantly, though, he reversed the rights arbitration award that had determined that supplementary compensation from the Alberta Heritage Foundation for Medical Research violated the association's exclusive bargaining rights.

At Athabasca, meanwhile, Sims ignored the line of arbitral argument that established that universities of similar size are appropriate comparators. He then, in apparent conflict with the replication principle, included the arbitrated settlement at the University of Calgary as well as the freely negotiated agreement at the University of Alberta in his pool. Both of these departures from the jurisprudential consensus bolstered his argument in favour of the employer's position.

\section{Conclusion: Is it Time to Defy the Law?}

It seems impossible, then, for academic staff to achieve breakthrough agreements through arbitration or to completely defend against employer attempts to weaken collective agreements. Other public sector workers in Alberta have challenged the limits and futility of interest arbitration by staging illegal walkouts. Nurses, health-care support workers and jail guards, among others, have all found it necessary to assert this right in defiance of the law in order to make wage and other workplace gains. While these workers have incurred the wrath of the courts in doing so, the collective agreements that have emerged from these actions are stronger than the ones they replaced. Is it time for academic staff to consider similar action?

Academic staff may not be desperate enough yet. National and competitive pressures have forced university employers to offer salaries, benefits and working conditions that are roughly comparable to those in place at other universities in the country. ${ }^{10}$ Furthermore, the division between contract language and salaries and benefits bargaining at three of the four Alberta universities, coupled with the condition that contract language stays in force unless both parties agree to a change, ensures that the employer is unable to weaken the non-monetary components of collective agreements without the consent of the faculty association. The employer, in other words, cannot unilaterally force concessions on academic staff. Even at Calgary, where interest arbitration applies to all aspects of the

\footnotetext{
${ }^{10}$ Does this mean that Alberta academic staff are free riders on the backs of academic staff elsewhere who have gone on strike for breakthrough agreements? The answer to this is beyond the scope of this paper, but evidence from the broader labour market would suggest that this is possible. Nonunionized workers at the Dofasco steel plant in Hamilton, for example, have long enjoyed similar salaries and benefits to those won by their fellow workers at unionized Stelco in the same city. The national and international markets for academic labour make such comparisons difficult, however. The Alberta market is determined in large part by what happens at the University of Alberta, which measures itself against other research-intensive universities such as the University of British Columbia, the University of Toronto (neither of which have experienced faculty strikes), and similarsized foreign institutions.
} 


\section{Compulsory Arbitration and the Right to Strike: \\ The Experience of Alberta's University Faculty}

collective agreement, employers are unable to force substantial concessions (like the elimination of mandatory retirement), even though they can win minor concessions from arbitrators. The other side of this, of course, is that under both the dual and unified approaches it is impossible to achieve significant gains without the agreement of the employer and, in the case of the dual systems, once a concession has been granted (normally but not always in return for a gain somewhere else) it cannot be regained without another concession.

Hence there are no compelling triggers such as attempted wage rollbacks, massive layoffs, or gutting of contracts that might prompt academic staff to consider strike action. However, the first decade of the twenty-first century might be the perfect time to launch strike action to take advantage of the fact that the provincial government's coffers are overflowing with money and education spending is a high priority for voters.

It is a major step to defy the terms of a collective agreement and launch an illegal strike, however. Planning is required and the costs have to be weighed against the benefits. First, an association in which discussions of strike action are foreign would have to shift its culture in order to include the strike option as part of its strategic arsenal. This would involve planning for a possible strike and, more importantly, educating and mobilizing the membership for strike action. Second, the association would have to prepare for the inevitable legal assault and the sanctions that would result. Assets would have to be protected from seizure, solidarity support would have to be arranged from other faculty associations and the broader labour movement, and the leadership and members would have to prepare for fines and jail time. In addition, faculty associations could lose the legal right to bargain for their members and collective agreements could be weakened or eliminated entirely.

Strikes, though, whether legal or illegal, are important educating and mobilizing events in themselves. Union members often emerge from both successful and unsuccessful strikes with a heightened sense of unity and union consciousness. And, of course, illegal strikes are often successful in achieving gains for members, and any sanctions imposed as a result of illegal action are often worth the sacrifice.

Is illegal strike action by Alberta academic staff a possibility in the foreseeable future? No. There is no evidence that any association is seriously considering this option or that there are members suggesting that such an approach be adopted. Nonetheless, it may simply be a matter of time before the limits of employer flexibility and the failure of the arbitration system force this group of workers to take the inevitable step and assert their right to withdraw their labour. 


\section{REFERENCES}

Adell, B. 1974. Collective Bargaining Rights for Faculty at the University of Alberta. Edmonton: Association of Academic Staff of the University of Alberta.

Athabasca University Faculty Association. 1977. Joe Pivato to Rev. E. Checkland, 13 December 1977, Athabasca University Faculty Association Collection.

Athabasca University Faculty Association. 2003. "Submission to the Final Selection Officer, 5 February."

Athabasca University Faculty Association and Athabasca University Governing Council. 2002. Terms and Conditions of Agreement Between Athabasca University Faculty Association and Athabasca University Governing Council, 2002-2004.

Athabasca University Governing Council, 2003. "Submission to the Final Selection Officer, 5 February."

Athabasca University Interim Governing Authority. 1977a. "Terms and Conditions of Appointment and Employment," Athabasca University Interim Governing Authority, Agenda Package, 18 April, Item 5.5. Attachment.

Athabasca University Interim Governing Authority. 1977b. John B. Dea to Barry Snowden, 25 April 1977, Agenda Package, 16 May.

Black, E. 1979. "Social relations and collective bargaining in the university." CAUT Bulletin, Vol. 26, No. 6, pp. 15-18.

CAUT Bulletin. 1973. "Calgary Faculty Supports Collective Bargaining," CAUT Newsletter, 21(4), (March), p. 3.

Caragata, W. 1979. Alberta Labour: A Heritage Untold. Toronto: James Lorimer and Company.

Finkel, A. 1988. “The Cold War, Alberta Labour, and the Social Credit Regime," Labour/Le Travail, Vol. 21, pp. 123-152.

Friedmann, K.A. 1973. "Collective Bargaining in Calgary." CAUT Bulletin, Vol. 21, No. 4, pp. 14-15. 


\section{Compulsory Arbitration and the Right to Strike: \\ The Experience of Alberta's University Faculty}

Fudge, J. and E. Tucker. 2001. Labour Before the Law: The Regulation of Workers' Collective Action in Canada, 1900-1948. Don Mills: Oxford University Press.

Geddes, E.F. 1990. “Alberta Labour Legislation under the Social Credit Government, 1935-1947,” LL.M. Thesis: University of Alberta.

Governors of the University of Calgary. 2002. "Submission of the Board of Governors to the Arbitration Board," In the Matter of an Interest Arbitration between The Governors of the University of Calgary and The University of Calgary Faculty Association, 6 November.

Haiven, L. 1995. "PC 1003 and the (Non)Right to Strike: A Sorry Legacy." In Labor Gains, Labour Pains: 50 Years of PC 1003. " C. Gonick, P. Phillips and J. Vorst (eds.). Winnipeg/Halifax: Society for Socialist Studies/Fernwood Books, pp. 215-236.

Harrison, T. and G. Laxer (eds.). 1995. The Trojan Horse: Alberta and the Future of Canada. Montreal: Black Rose Books.

Hawco, G. 1985. The Athabasca University Governing Council and the Athabasca University Faculty Association. ([unreported] 19 June).

International Labour Organisation. 1977. Official Bulletin, Reports of the Committee on Freedom of Association, Case No. 893 "Complaint Presented by the Canadian Labour Congress and the Canadian Association of University Teachers Against the Government of Canada," 187th Report and 194th Report.

Jackson, R.L. and M. Teplitsky. 1998. "Ability to Pay and the Independence of Arbitration: Arbitrators' Perspectives.” In Labour Arbitration Yearbook 1998. W. Kaplan, J. Sack, M. Gunderson and R. Filion (eds.). Toronto: Lancaster House, pp. 341-364.

Jones, D. 1993. University of Lethbridge Board of Governors and University of Lethbridge Faculty Association. ([unreported] 3 August).

Jones, D. and R. Neuman and L. Kanee. 2002. The Governors of the University of Calgary and The Faculty Association of the University of Calgary. ([unreported] 16 December).

Lisac, M. 1995. The Klein Revolution. Edmonton: NeWest. 
Lowe, R. 1978. “Government Policy vs. bargaining rights.” CAUT Bulletin, Vol. 25, No. 7, pp. 11, 17, 21.

McCallum, M.E. 1990. "The Mines Arbitration Act, 1888: Compulsory Arbitration in Context." In Essays in the History of Canadian Law, Volume III, Nova Scotia. P. Girard and J. Phillips (eds.). Toronto, University of Toronto Press, pp. 303-325.

Panitch L. and D. Swartz. 1993. From Consent to Coercion: The Assault on Trade Union Freedoms: From Wage Controls to Social Contract Toronto: Garamond Press.

Ponak, A. 1993. Athabasca University Governing Council and Athabasca University Faculty Association. ([unreported] 10 November)

Ponak, A. and Y. Reshef and D.G. Taras. 2003. "Alberta: Industrial Relations in a Conservative Climate." In Beyond the National Divide: Regional Dimensions of Industrial Relations. M. Thompson and J.B. Rose and A.E. Smith (eds.). Montreal and Kingston: McGill-Queen's University Press, pp. 267-306.

Roydhouse, R.H. 1978. “'Special Plan' bargaining: Model best suited for UBC faculty." CAUT Bulletin. Vol. 25, No. 7, pp. 15-16.

Sims, A. 2000. University of Alberta and Association of Academic Staff: University of Alberta. ([unreported] 18 July).

Sims, A. and L. Cassidy and G. England. 2001. The University of Calgary and The University of Calgary Faculty Association. ([unreported] 13 August).

Sims, A. 2003. Athabasca University Governing Council and Athabasca University Faculty Association. ([unreported] 29 September).

Smith, J.E. 1978. "Non-certified Agreements: the Toronto approach.” CAUT Bulletin. Vol. 25, No. 7, p. 16.

Snow, H. 1983a. "Bargaining Talk," CAUT Bulletin, Vol. 30, No. 6, p. 10.

Snow, H. 1983b. "Bargaining Talk," CAUT Bulletin, Vol. 30, No. 7, p. 14.

An Act Respecting the Conditions of Labour and Welfare of Employees in the Province. SA 1947. Chapter 8. 
An Act to amend the Alberta Labour Act. SA 1948. Chapter 76.

An Act respecting the Public Service. SA 1968. Chapter 81.

An Act respecting Negotiations between the Boards and agencies of the Crown and Their Employees. SA 1968. Chapter 17

The Public Sector Employee Relation Act. SA 1977. Chapter 40.

The Universities Amendment Act. SA 1981. Chapter 61.

Taylor, G. 1991. The Governors of the University of Alberta and the Association of Academic Staff of the University of Alberta. ([unreported] 10 June 1991).

Taylor, J. n.d. Personal Papers.

Tudiver, N. 1999. Universities for Sale: Resisting Corporate Control over Canadian Higher Education. Toronto: James Lorimer and Company.

Unger, G. 1978. "Final Offer Selection: An Alberta experiment in interest arbitration." CAUT Bulletin, Vol. 25, No. 12, pp. 12-14.

Vanderberg, R.D. 1978. "Interest arbitration at the University of Calgary." CAUT Bulletin, Vol. 25, No. 12, p. 15.

Weiler, J.M. (ed.). 1981. Interest Arbitration: Measuring Justice in Employment. Toronto: The Carswell Company.

Weiler, P. 1980. Reconcilable Differences: New Directions in Canadian Labour Law. Toronto: The Carswell Company Limited. 